\title{
A new name in Centaurea (Asteraceae, Cardueae) from Turkey
}

\author{
Elaheh Oreizi, Kazem Negaresh \& Mohammad Reza Rahiminejad
}

\begin{abstract}
OREIZI, E., K. NEGARESH \& M.R. RAHIMINEJAD (2017). A new name in Centaurea (Asteraceae, Cardueae) from Turkey. Candollea 72 : 319-322. In English, English abstract. DOI: http://dx.doi.org/10.15553/c2017v722a7

Centaurea zaferii Negaresh is proposed as a new name for Centaurea foliosa Boiss. \& Kotschy published by Boissier in 1875, a later homonym of Centaurea foliosa Gand. published by Gandoger in 1873. The description of Centaurea zaferii is amended with characters of mature flowers and achenes. Centaurea zaferii is morphologically similar to Centaurea charrelii Halácsy \& Dörfler and a discussion of their diagnostic characters is presented. In addition, the geographical distribution and habitat of Centaurea zaferii are presented.
\end{abstract}

\section{Keywords}

ASTERACEAE - Cardueae - Centaurea - Nomenclature - Taxonomy - Turkey

Addresses of the authors:

EO, MRR: Department of Biology, University of Isfahan, Isfahan 81746-73441, Iran. E-mail: mrrsci@gmail.com

KN: Department of Horticulture, Faculty of Agriculture, Ramin Agriculture and Natural Resources University of Khuzestan, Mollasani, Ahvaz, Iran.

Submitted on January 12, 2017. Accepted on June 30, 2017.

First published online on July 20, 2017.

ISSN : 0373-2967 - Online ISSN : 2235-3658 - Candollea 72(2): 319-322 (2017)

C CONSERVATOIRE ET JARDIN BOTANIQUES DE GENÈVE 2017 


\section{Introduction}

Centaurea L. s.l. with c. 600 species is among the largest genera in Asteraceae (Hellwig, 2004). This genus of 40 sections occurs mainly in the Mediterranean and Irano-Turanian regions (López et al., 2011; Negaresh \& RahimineJAD, 2014). Species of Centaurea sect. Cynaroides Boiss. are characterized by a large habit, a capitula arranged in a spikelike or raceme-like inflorescence, and especially by entire hastate leaves (Garcia-Jacas et al., 2006; Negaresh \& RAHIMINEJAD, 2014, 2016).

In the course of our research on Centaurea sect. Cynaroides (Ranjbar et al., 2012, 2013; Negaresh \& Rahiminejad, 2014, 2015, 2016; Negaresh et al., 2014, 2015; Ranjbar \& Negaresh, 2014a, 2014b), we noticed that Centaurea foliosa Boiss. \& Kotschy (Boissier, 1875) is an illegitimate name because it is a later homonym of $C$. foliosa Gand. (GAndoger, 1873). We therefore proposed here a replacement name for this taxon: C. zaferii Negaresh. Recent collections in Hatay Province in southern Turkey of mature capitula compared with collections held at B, C, G, GOET, ISTE, JE, K, P, and W herbaria allows to improve the description of this species that was previously know only from immature capitula by BoIssien (1875) and Wagenitz (1975).

Scanned images of Boissier's type collection is available online via the Catalogue des Herbiers de Genève (2017).

\section{Nomenclature and taxonomy}

Centaurea zaferii Negaresh, nom. nov.

$\equiv$ Centaurea foliosa Boiss. \& Kotschy in Boiss., Fl. Orient. 3: 672.1875 [non C. foliosa Gand.].

Typus: Turkey. Prov. Hatay : "in valle Amani occidentalis supra Arsus [Arsuz] prope pagum Ursusa”, c. $150 \mathrm{~m}$, 4.VII.1862, Kotschy 113 (holo-: G-BOIS [G00150226] images seen; iso-: C [C10007081] image seen, JE [JE00015828] image seen, K [K000794179] image seen, P [P00730189, P00730190] images seen, S [S10-6178] image seen, W0075111,W0075112, W0075110 images seen) (Fig. 1).

Biennial herb, $100-150 \mathrm{~cm}$ tall. Stem erect, branched in the upper third, greenish, c. $6 \mathrm{~mm}$ in diam. at base, cylindrical, with thick yellowish striations, \pm densely leafy throughout, subglabrous or with sparsely arachnoid trichomes. Leaves coriaceous (papyraceous when dry), sparsely covered with arachnoid trichomes, denser along midrib and veins. Basal and lower cauline leaves very large $60-77 \times 10-15 \mathrm{~cm}$, petiolate, hastate, oblong or oblong-lanceolate, with 1-2 pairs of \pm falcate or triangular lobes (4-8 cm long) in lower part, denticulate, truncate at base, obtuse or acute at apex, with prominent and elevated veins on both sides. Median cauline leaves sessile, simple, narrowly oblong or oblong-lanceolate, 10-15 $\times 3-5 \mathrm{~cm}$, entire, acuminate at apex, decurrent. Upper cauline leaves gradually smaller towards apex, sessile, simple, lanceolate, 4-9 $\times 1.5-2.2 \mathrm{~cm}$, usually longer than capitula, decurrent, entire, acuminate at apex. Capitula several, (8-)10-25-cephalous, arranged in a subraceme or racemose-dichasium, 2-3 grouped subsessilly at apex of stem and of several short axillary branches. Involucres oblong-ovoid, 23-25 × 13-25 mm. Phyllaries multiseriate, greenish-yellow, imbricate, coriaceous. Appendages large, totally concealing the phyllaries, chartaceous, not decurrent, straw-coloured, lanceolate, 2-3 $\mathrm{mm}$ wide at base (excluding cilia); cilia numerous, erect, (8-)12-14 on each side, $1.5-3 \mathrm{~mm}$ long; apical spine short, 3-5 mm long, slightly longer than the adjacent cilia. Flowers yellow; central florets hermaphroditic, 28-30 mm long, corolla 12-13 mm long, 5-lobed, lobes 6-7 mm long, anther tube yellowish, apical appendage broadly rounded, style slightly shorter than corolla in length, stigma bifid, ca. $0.5 \mathrm{~mm}$ long; peripheral florets sterile, nearly equal in length than the central ones, numerous (15-20 in each capitulum) and conspicuous, finely dissected, slightly radiant, 4-lobed, limb lobes linear. Achenes lanceolate-oblong, c. 4.5-5 $\times 2-2.5 \mathrm{~mm}$, striate and shiny, brown to dark brown or silverbrown, rounded at apex, glabrous; insertion areole lateral, yellowish or light-brown, c. $0.5 \mathrm{~mm}$ long. Pappus double, persistent, multiseriate, scabrous, brown or dark brown, sometimes dark purple, 5-7 $\mathrm{mm}$ long, the bristles of the inner side rows shorter than those of the outer side, c. $1.5 \mathrm{~mm}$ long.

Etymology. - The specific epithet honors Dr. Zafer Kaya a specialist of the genus Centaurea s.l. in Turkey.

Phenology. - Flowering from July to August; fruit ripening from July to September.

Distribution and habitat. - Centaurea zaferii is a very rare endemic to Hatay Province in southern Turkey. It is an IranoTuranian element (Negaresh \& Rahiminejad, 2016), and grows on rocky slopes, limestone cliffs, gravel slopes, or in forest dominated by Cupressus sempervirens L. This species also grows on forest slopes or scattered between Rosa L. shrubs, and in the low-montane zone at elevation of c. $150 \mathrm{~m}$. Centaurea zaferii is distributed in lower elevation in comparison to the other species of Centaurea sect. Cynaroides.

Notes. - Boissier (1875) described C. foliosa ( $\equiv$ C. zaferii) based on an immature specimens and was not able to study the characters of flowers and achenes. New collections from 1994 and 2014 allow to better understand the morphology of this species. Centaurea zaferii resembles $C$. charrelii Halácsy $\&$ Dörfl. by its yellow flowers and the chartaceous, lanceolate appendages of the capitulum (totally concealing the phyllaries). However, C. zaferii differs from C. charrelii by its taller 


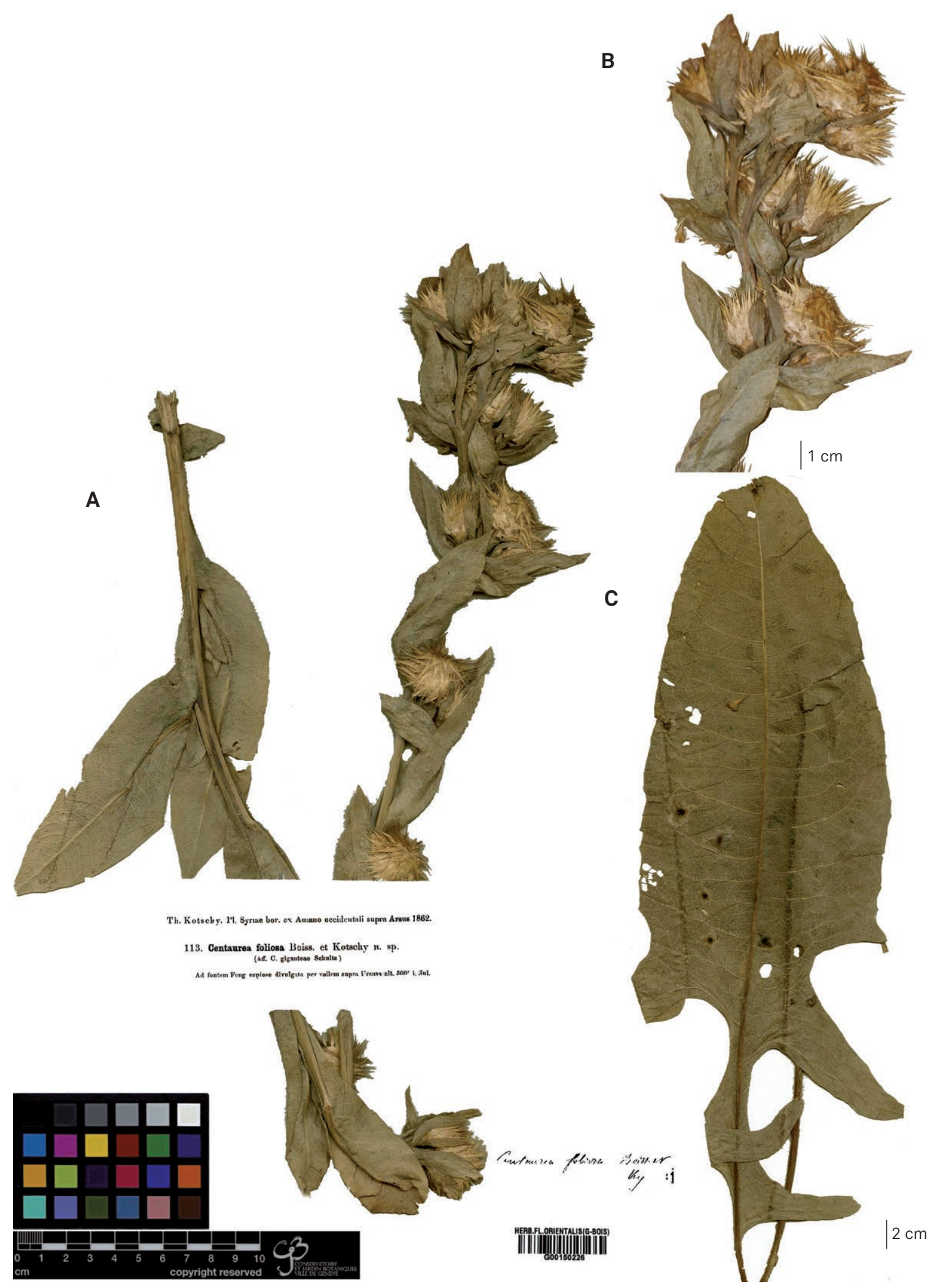

Fig. 1. - Details of holotype of Centaurea zaferii Negaresh (ㄷ. foliosa Boiss. \& Kotschy) in G-BOIS. A. Habit; B. Inflorescence; C. basal leaf. 
habit (100-150 cm vs 50-70 cm), basal and lower cauline leaves with 1-2 pairs of \pm falcate or triangular lobes (4-8 cm long), denticulate (vs undivided, oblong or oblong-lanceolate, margin smooth), capitula in groups of 2-3 arranged subsessilly at apex of stem and of several short axillary branches (vs a crorymb of 5 to $10(-15)$ capitula), involucres $23-25 \times 13-25 \mathrm{~mm}$ (vs $25-32$ $\times 25-32 \mathrm{~mm}$ ), appendages 2-3 mm (vs 3-5 mm) wide at base (excluding cilia), peripheral florets equal than the central ones, 4-lobed (vs slightly shorter than the central ones, 5-lobed), achenes c. 4.5-5 mm (vs 5-6 mm) long, and pappus brown or dark brown (vs whitish).

Centaurea zaferii is endemic to low elevation (c. $150 \mathrm{~m}$ ) in Hatay Province in southern Turkey whereas C. charrelii grows at higher elevation (c. $500 \mathrm{~m}$ ) in eastern Greece (Edhessa, Domokos and Macedonia) (Constantinidis et al., 2002).

Specimens examined. - Turkey. Hatay: "Höyük Köy, südöstlich Arsuz (Ulucinar), am Bachufer”, c. 150 m, 11.VIII.1994, Hellwig छ Kaya s.n. (GOET); "Antakya, Kiseciküstleri,”14.VII.2014, Bona 102867 (ISTE).

\section{Acknowledgements}

The authors are greatly thankful of the collaborators of the following herbaria: B, C, G, GOET, ISTE, JE, K, P, and W for their contribution during the revision of material and for providing the images of types. We are most grateful to Dr. Mehmet Bona for sending herbarium specimens, two anonymous reviewers and Martin Callmander and Laurent Gautier for their support in bringing this manuscript into publication.

\section{References}

Boissier, E. (1875). Fl. Orient. vol. 3.

Catalogue des Herbiers de Genève [CHG] (2017). Base de donnés des herbiers en ligne du Conservatoire et Jardin botaniques de la Ville de Genève [http://www.ville-ge.ch/musinfo/ $\mathrm{bd} / \mathrm{cjb} / \mathrm{chg} /$ index.php?lang=en].

Constantinidis, T., E.P. Bareka \& G. Kamari (2002). Karyotaxonomy of Greek serpentine angiosperms. Bot. J. Linn. Soc. 139: 109-124.

Gandoger, M. (1873). Observations sur les Centaurea decipiens (Thuill.) transalpina (Schleich.) et tubulosa (Chabert). Taranne, Paris.

Garcia-Jacas, N., T. Uysal, K. Romashchenko, V.N. SuárezSantiago, K. Ertuğrul \& A. Susanna (2006). Centaurea revisited: A molecular survey of the Jacea Group. Ann. Bot. 98: 741-753.
Hellwig, H. (2004). Centaureinae (Asteraceae) in the Mediterranean - history of ecogeographical radiation. Pl. Syst. Evol. 246: 137-162.

López, E., J.A. Devesa \& I. Arnelas (2011). Taxonomic study in the Centaurea longei complex (Asteraceae). Ann. Bot. Fennici 48: 1-12.

Negaresh, K. \& M.R. Rahiminejad (2014). A contribution to the taxonomy of Centaurea sect. Cynaroides (Asteraceae, CardueaeCentaureinae) in Iran. Phytotaxa 158: 229-244.

Negaresh, K. \& M.R. Rahiminejad (2015). The identity and revised circumscription of Centaurea iranshahrii (Asteraceae, Cardueae-Centaureinae) in Iran. Feddes Repert. 126: 55-66.

Negaresh, K. \& M.R. Rahiminejad (2016). Centaurea rahiminejadii sp. nov. and a new record in the genus Centaurea (Asteraceae, Cardueae-Centaureinae) from Iran. Nord. J. Bot. 34 : 15-22.

Negaresh, K., Z. Kaya \& M.R. Rahiminejad (2015). Centaurea sennikoviana (Asteraceae, Cardueae), a new species from central Anatolia, Turkey. Ann. Bot. Fennici 52: 321-327.

Negaresh, K., M. Ranjbar \& M.R. Rahiminejad (2014). Centaurea alfonsoi (Asteraceae, Cardueae), a new species from Iran. Ann. Bot. Fennici 51 : 195-199.

Ranjbar, M. \& K. Negaresh (2014a). The genus Centaurea (Asteraceae, Cardueae) in Iran: two new species and a lectotypification. Edinb. J. Bot. 71:51-56.

Ranjbar, M. \& K. Negaresh (2014b). Taxonomic notes and two new species in Centaurea sect. Cynaroides (Compositae, Cardueae) from Iran. Novon 23:321-327.

Ranjbar, M., K. Negaresh \& R. Karamian (2012). Centaurea regia subsp. javanroudensis, a new subspecies of Centaurea sect. Cynaroides (Asteraceae), from flora of Iran. Biol. Diversity $\mathcal{E}^{\circ}$ Conservation 5 : 5-10.

Ranjbar, M., K. Negaresh \& R. Karamian (2013). Centaurea shahuensis and C. ravansarensis spp. nov. (Asteraceae, Cardueae) from west Iran. Nord. J. Bot. 31: 430-436.

Wagenitz, G. (1975). Centaurea L. In: Davis, P.H. (ed.), Fl. Turkey 5. 